\title{
An Empirical Study on Exploring Relationship among Information Quality, E-satisfaction, E-trust and Young Generation's Commitment to Chinese Online Retailing
}

\author{
- Ziaullah Muhammad, Feng Yi, Akhter Shumaila Naz, Khan Muhammad \\ Fahad
}

\begin{abstract}
The purpose of this study is to investigate the relationship among online retailing information quality, e-satisfaction, e-trust and young generation customer's commitment in mainland China. The study variables have considerable importance in e-tailers performance. The data were collected based on a sample of 383 students from Chinese universities during the first quarter of 2014. We used confirmatory factor analysis (CFA) and structural equation modeling (SEM) to evaluate the hypotheses about the relationship among model constructs. Thus, all the hypotheses developed in the study were positively confirmed except one. Therefore, the investigated variables are reinforcing the theory and previous research in this field. This study reveals interesting implications of information quality, e-satisfaction, e-trust and customers commitment that are useful to both academicians and practitioners.
\end{abstract}

Keywords: commitment, e-satisfaction, e-trust, information quality, online retailing.

JEL Classification: M1, L81

\section{INTRODUCTION}

In response of e-commerce market competitiveness commitment has great recognition and importance in the literature of relationship marketing. It is a key precursor to the accomplishment of valuable outcomes for instance, future intentions (Kim et al., 2005), and profitability (Anderson \& Weitz, 1992). Customer commitment refers as an attitude that reflects the desire to maintain a valued relationship (Moorman, 1992; Morgan \& Hunt, 1994). Moreover, it is also conceptualized as a "pledge of continuity" form one party to another (Dwyer et al., 1987). Consequently, it is argued that the commitment lies potential for scarifies or sacrifice that one party faces in the event that the relationship ends (Anderson \& Weitz, 1992), or for the sake of alternative seeking from the market (Gundlach et al., 1995). Sometimes commitment refers as a resistance to change (Pritchard et al., 1999), and a sort of attitude change (Ahluwalia, 2000). Particularly, marketing scholars and researchers used various definitions and perspective to characterize two important components of commitment (Gundlach et al., 1995). The first component of commitment is based on liking and identification and second component is based on dependence and switching cost that are called affective and continuance commitment respectively (Allen \& Meyer, 1990). 
The affective commitment is based on the "affective or emotional attachment to the organization such that the strongly committed individual identifies with, is involved in, and enjoys membership in the organization" (Allen \& Meyer, 1990). Thus the essence of affective commitment is that customers indulge to acquire an emotional attachment to their partner in a consumption relationship. As customer like to any specific brand or service providers (e-tailers), at that movement they are experiencing the psychological state of affective commitment (Fullerton, 2003). While continuance commitment in exchange relationship is built on the side bets, switching costs and scarcity of alternatives (Allen \& Meyer, 1990).

The core concept of marketing paradigm has been investigated by researchers in both business to business (Morgan \& Hunt, 1994), and consumer's context (Verhoef et al., 2002). In recent years, internet has had a profound impact on the subject of marketing. Recently most of the consumers feel comfortable buying products through online mechanism. Therefore, e-tailers have attempted to design website to attract customers to visit and revisit their sites. Some studies have investigated the factors that could affect customers purchase behavior on the Web (Poddar et al., 2009).

The purpose of this study is to propose and demonstrate a model of the commitment for online retailers, incorporating e-tail information quality, e-satisfaction and e-trust. This research intends to focus on consumer's attitude and behaviors intentions towards e-tailing, not a specific brand or manufacturer. We maintain that e-tailing information quality have different impact on consumer's e-satisfaction, e-trust which in turn leads to commitment. This study begins with the introduction, proposed model and the hypotheses. We then describe the research methodology, present our research results and discussion, and conclude with managerial implications, limitations and suggestions for future research.

\section{LITERATURE REVIEW AND RESEARCH HYPOTHESES}

This study draws from previous theories to develop hypotheses with regard to the impact of e-tailing information quality on e-satisfaction, e-trust and commitment. We derive a theoretical framework in Fig.1, which illustrates the hypothesized relationships discussed in the subsequent sections.

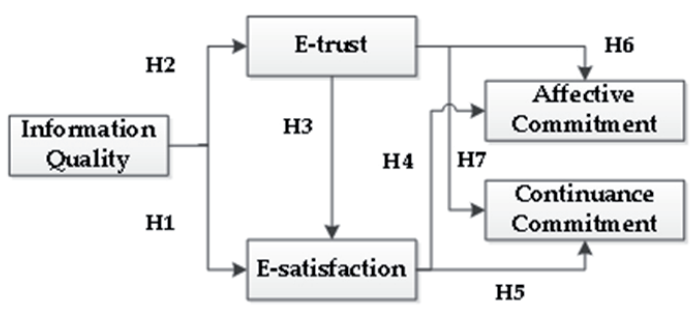

Fig.1 Theoretical Framework.

\subsection{Relationship between e-tailing information quality, e-trust and e-satisfaction}

Information quality contents are necessary for online shopping decisions. It might be in the shape of type, variety and detail information that usually determined in the system design and 
development phase (Ahn et al., 2007). The most common characteristics of information quality are currency, accuracy, completeness, understandability and timeliness (Lederer et al., 2000; Chuan-Chuan Lin \& Lu, 2000). Generally, information quality is helpful for online customers to make better alternatives comparison, to better choice selection and over all online shopping decision making. Researches have been concentrated and focused the importance of certain measures about information quality such contents and contents quality in the context of online shopping (Palmer, 2000; Ranganathan \& Ganapathy, 2002). Specifically such characteristics of these measures have enhanced the intrinsic and extrinsic belief of e-customers towards online shopping (Ahn et al., 2007; Chuan-Chuan Lin \& Lu, 2000).

It is indicated that online customers have enough concerned to providing their personal information to online retailers (Janda et al., 2002; Vijayasarathy, 2004). Perhaps, financial and personal security of information has been determined as measure of online customer's satisfaction (Park and Kim, 2003). It is investigated that information quality has played important role and effects on customer satisfaction with internet shopping (Liu et al., 2000; Bai et al., 2008). Bharati and Chaudhury (2004) found that information quality is positively and directly correlated with customer's e-satisfaction. By information quality in online retailer website has been improved customers decision making satisfaction. Lin (2007) stated that information quality is the most important factor in the context of e-satisfaction of online customers. McKnight et al. (2002) indicated that Website design contents are the antecedents of customers trust in internet shopping. Whereas Cyr (2008) has been investigated to some extent different results and stated that information design has positively and directly influence customer trust in Canada but not in China and Germany. Information has been considered as an important element and prerequisite of trust and satisfaction (Wang \& Emurian, 2005; Flavián et al., 2006). Therefore, we proposed subsequent hypothesis.

\section{H1: Information quality positively influences e-satisfaction}

\section{H2: Information quality positively influences e-trust}

\subsection{The relationship between e-trust and e-satisfaction}

In the context of e-tailing, online customer satisfaction is quite difficult before gain their trust. Therefore, trust also affects e-satisfaction in this regard. According to Berry (2000), trust is very essential for satisfaction. In fact, online consumer who trusts on e-tailers will be satisfied and more willing to commit on it. Yoon (2002) have examined the correlation between trust and satisfaction. Researchers have been considered trust as critical determinants of developing relationship between buyers and sellers (Sirdeshmukh et al., 2002; Verhoef et al., 2002). It is also investigated that trust has direct influence on the post purchase satisfaction. Specifically in the context of online shopping trust might be the fundamental element for initiating the transaction. Thus customer perceives a higher level of risk in e-tailing than in traditional retailing in the shape of delivery, information disclosure and payment. In this regard online customer prefers to make transaction with those e-tailers they can trust more (Singh \& Sirdeshmukh, 2000). It is found that trust is the predictor of e-satisfaction in e-commerce (Harris \& Goode, 2004; Jin \& Park, 2006). Therefore, we proposed subsequent hypothesis.

H3: E-trust positively influences e-satisfaction 


\subsection{The relationship between e-satisfaction and commitment}

Satisfaction refers as "an overall evaluation based on the total purchase and consumption experience with a good or service over time" (Anderson et al., 1994). Thus, e-satisfaction is the precursor of customers' commitment; actually it is the result of customer's evaluations regarding the product and the key elements of their decision to repurchase (Kasmer, 2005). Consequently, customer satisfaction is one of values for customers that they expect from firm to deliver in the context of exchange. We would expect that commitment is one of the favorable consequences of satisfaction (Bansal et al., 2004). Similarly online customers over all evaluations of satisfactory consumption experiences make a positive impact on the degree of commitment in the relationship (Brown et al., 2005). Previously, it is observed that satisfaction has positive influence on commitment (Vasudevan et al., 2006; Abdul-Muhmin, 2005). In line with these authors, we propose that in the context of online shopping e-satisfaction is positively associated with affective and continuance commitment. Thus, we proposed subsequent hypothesis.

\section{H4: E-satisfaction positively influences affective commitment}

H5: E-satisfaction positively influences continuance commitment

\subsection{The relationship between e-trust and commitment}

Trust refers as "a willingness to rely on an exchange partner in whom one has confidence" (Moorman et al., 1992). Practically it is observed that expectation of trustworthiness results from the ability to expertise, reliability and intentionality. Morgan and Hunt (1994) defined trust as the confidence in the exchange partner's ability, reliability and integrity (Allen \& Meyer, 1990). Trust is the determinant of commitment and successful business relationship (Morgan \& Hunt, 1994). It is found that trust influenced positively on commitment (Tellefsen, 2002). Therefore, it is suggested that trust influenced firms to focus on the positive motivation to stay in the relationship based on the feeling of connectedness and identification with each other (affective commitment), less due to continuance (continuance commitment) reasons to stay with the supplier (De Ruyter et al., 2001). Thus, we proposed subsequent hypotheses.

H6: E-trust positively influences affective commitment

H7: E-trust positively influences continuance commitment

\section{RESEARCH METHODOLOGY}

\subsection{Questionnaire design}

We reviewed the literature to explore valid measures for this study related constructs and adapted existing scales to measure e-tailing information quality (Ahn et al. 2005) influence on e-satisfaction (Fornell et al. 1996; Kim et al. 2009), e-trust (Garbarino and Johnson 1999; Ribbink et al. 2004) and commitment (Fullerton, 2003). Firstly, scales from literature were explored in English, therefore initial questionnaire was developed in English. Then, English version questionnaire were translated into Chinese by two Chinese Master and Ph. D students. Further, Chinese version questionnaire were translated back into English, hence this version of questionnaire was counter checked against the original English version for discrepancies and their rectifica- 
tion. This approach has been adopted to facilitate appropriate measurement development and to confirm meaning consistency, to improve understandability of the survey and proper use of terminology in Chinese. In this study all the indicators in the questionnaire were measured using a 7-Point Likert scale ranging from strongly disagree to strongly agree (1= strongly disagree; $7=$ strongly agree).

\subsection{Sampling and data collection}

Fung Business Intelligence Center investigated that Chinese online customers are young people and over 60\% were aged 30 or below in 2012. It is highlighted that middle aged customers preferred to buy online due to more buying power (Fung Business Intelligence Center 2013). Particularly, it is recommended that universities students are likely to be the first and more attractive potential consumers segment of e-commerce due to their high education level and income (Lightner et al. 2002). Therefore, in this study we used convenience sampling and paper survey approach to collect data from universities different locations such as libraries, research labs, canteens and mini markets in mainland China. Initially we distributed five hundred questionnaires to respondents, but 430 respondents have completed and returned the questionnaires. The response rate 86 percent. Out of 430 collected, 47 questionnaires were found to be unreliable. Therefore, data analyses were conducted on 383 usable questionnaires. The profile of respondents and their characteristics are stated in Table 1.

Tab. 1 - Respondent profile ( $\mathrm{n}=383)$. Source: Authors Own

\begin{tabular}{|l|l|c|c|}
\hline Demographics Variable & Category & Sample & Ratio \\
\hline \multirow{4}{*}{ Gender } & Male & 222 & $58.0 \%$ \\
\cline { 2 - 4 } & Female & 161 & $42.0 \%$ \\
\hline \multirow{4}{*}{ Age (Years) } & Below-20 & 79 & $20.6 \%$ \\
\cline { 2 - 4 } & $20-29$ & 299 & $78.1 \%$ \\
\cline { 2 - 4 } & $30-39$ & 5 & $1.3 \%$ \\
\hline \multirow{5}{*}{ Sducation Level } & High School & 3 & $0.8 \%$ \\
\cline { 2 - 4 } & Bachelor & 218 & $56.9 \%$ \\
\cline { 2 - 4 } & Master & 147 & $38.4 \%$ \\
\cline { 2 - 4 } & Ph. D & 15 & $3.9 \%$ \\
\hline Profession & Students & 383 & $100 \%$ \\
\hline \multirow{3}{*}{ Shopping Experience (Years) } & Under-1 & 48 & $12.5 \%$ \\
\cline { 2 - 4 } & $1-4$ & 239 & $62.4 \%$ \\
\cline { 2 - 4 } & Over-4 & 96 & $25.1 \%$ \\
\hline
\end{tabular}

\subsection{Construct development}

In this study we used Kaiser-Meyer-Olkin (KMO) to measure sampling adequacy and the Bartlett test of sphericity. The results that showed KMO value of 0.889 with the significance of Bartlett's test at 0.000 level, indicates the data for exploratory factor analysis (EFA) fitting. We used maximum likelihood analysis for data reduction and promax rotation with Kaiser Normali- 
zations for clarifying the factors. Hence EFA was conducted with specifying four numbers of factors. The cumulative variance explanation reaches $66 \%$. All the items have strong loadings on the construct in the pattern matrix which are $>0.30$ (Hair et al., 1998). The results of EFA are shown in Table 2 .

The internal consistency reliability of all items was examined by Cronbach alpha and item to total correlations. Therefore, the alpha coefficients and item to total correlations for each construct are shown in Table 3. The Cronbach's alpha of all measurement constructs ranges from 0.94 to 0.84 . A Cronbach's alpha of value 0.7 or higher is commonly considered as a cut off for reliability (Nunnally 1978; Hair et al. 2006). Convergent validity has been examined based on measurement items standardized factor loadings, composite reliability and the variance extracted measures.

The results of convergent validity test are also presented in Table 3. Standardized factor loadings of all items in each construct range from i.e. information quality (0.913-0.739), e-satisfaction (0.887-0.862), e-trust (0.898-0.671), affective commitment (0866-0.658) and Continuance commitment (0.866-0.677) that exceed the recommended level of 0.60 (Hair et al. 1998). The composite reliabilities (CR) range from 0.96 (e-satisfaction) to 0.87 (continuance commitment) which exceed the recommended level of 0.70 . The average variance extracted (AVE) measure ranges from 0.71 (information quality \& e-satisfaction) to 0.59 (E-trust) which is better than recommended value of 0.50 (Hair et al. 1998). The higher value of AVE, CR and factor loadings results, therefore adequately demonstrates the convergent validity of the measurement items.

Tab. 2 - Results of exploratory factor analysis (EFA). Source: Authors Own

\begin{tabular}{|c|c|c|c|c|c|}
\hline $\begin{array}{l}\text { Construct } \\
\text { Items }\end{array}$ & $\begin{array}{c}\text { Information } \\
\text { Quality }\end{array}$ & e-Satisfaction & e-Trust & $\begin{array}{l}\text { Affective } \\
\text { Commitment }\end{array}$ & $\begin{array}{l}\text { Continuance } \\
\text { Commitment }\end{array}$ \\
\hline IQ1 & 0.666 & & & & \\
\hline IQ2 & 0.915 & & & & \\
\hline IQ3 & 0.889 & & & & \\
\hline IQ4 & 0.941 & & & & \\
\hline IQ5 & 0.848 & & & & \\
\hline IQ6 & 0.907 & & & & \\
\hline IQ7 & 0.705 & & & & \\
\hline S1 & & 0.824 & & & \\
\hline S2 & & 0.886 & & & \\
\hline S3 & & 0.877 & & & \\
\hline T1 & & & 0.601 & & \\
\hline $\mathrm{T} 2$ & & & 0.631 & & \\
\hline T3 & & & 0.575 & & \\
\hline $\mathrm{T} 4$ & & & 0.812 & & \\
\hline
\end{tabular}




\begin{tabular}{|c|l|l|l|l|l|}
\hline T5 & & & 0.820 & \\
T6 & & & 0.757 & & \\
\hline AF1 & & & 0.817 & \\
AF2 & & & 0.897 & \\
AF3 & & & 0.795 & \\
AF4 & & & & 0.706 & \\
\hline CC1 & & & & 0.491 \\
CC2 & & & & & 0.789 \\
CC3 & & & & 0.460 \\
CC4 & & & & \\
\hline
\end{tabular}

Extraction Method: Maximum Likelihood. Rotation Method: Promax with Kaiser Normalization. a. Rotation converged in Giterations. *(IQ: Information Quality, S: Satisfaction, T: Trust, AF: Affective Commitment, CC: Continuance Commitment, L: e-Loyalty)

Tab. 3 - Results of internal reliability and convergent validity tests. Source: Authors Own

\begin{tabular}{|c|c|c|c|c|c|c|}
\hline \multicolumn{4}{|c|}{ Internal Reliability } & \multicolumn{3}{|c|}{ Convergent Validity } \\
\hline Construct & items & $\begin{array}{l}\text { Cronbach } \\
\alpha\end{array}$ & $\begin{array}{l}\text { Item Total } \\
\text { Correlation }\end{array}$ & $\begin{array}{l}\text { Standardized } \\
\text { Factor Loadings }\end{array}$ & $\begin{array}{l}\text { Composite } \\
\text { Reliability }\end{array}$ & $\begin{array}{l}\text { Variance } \\
\text { Extraced }\end{array}$ \\
\hline $\begin{array}{l}\text { Information } \\
\text { Quality }\end{array}$ & $\begin{array}{l}\text { IQ1 } \\
\text { IQ2 } \\
\text { IQ3 } \\
\text { IQ4 } \\
\text { IQ5 } \\
\text { IQ6 } \\
\text { IQ7 }\end{array}$ & 0.94 & $\begin{array}{l}0.691 \\
0.849 \\
0.846 \\
0.876 \\
0.858 \\
0.847 \\
0.746\end{array}$ & $\begin{array}{l}0.739 \\
0.850 \\
0.859 \\
0.913 \\
0.884 \\
0.892 \\
0.757\end{array}$ & 0.95 & 0.71 \\
\hline E-Sat & $\begin{array}{l}\text { S1 } \\
\text { S2 } \\
\text { S3 }\end{array}$ & 0.90 & $\begin{array}{l}0.813 \\
0.808 \\
0.810\end{array}$ & $\begin{array}{l}0.887 \\
0.862 \\
0.865\end{array}$ & 0.96 & 0.71 \\
\hline E-Trust & $\begin{array}{l}\text { T1 } \\
\text { T2 } \\
\text { T3 } \\
\text { T4 } \\
\text { T5 } \\
\text { T6 }\end{array}$ & 0.86 & $\begin{array}{l}0.642 \\
0.638 \\
0.567 \\
0.687 \\
0.694 \\
0.670\end{array}$ & $\begin{array}{l}0.698 \\
0.679 \\
0.671 \\
0.798 \\
0.898 \\
0.835\end{array}$ & 0.90 & 0.59 \\
\hline
\end{tabular}




\begin{tabular}{|l|l|l|l|l|l|l|}
\hline & AF1 & 0.88 & 0.680 & 0.658 & 0.88 & 0.64 \\
Aff. & AF2 & & 0.818 & 0.823 & & \\
& AF3 & & 0.765 & 0.866 & & \\
& AF4 & & 0.743 & 0.842 & & \\
\hline \multirow{3}{*}{ Cont. Comt. } & CC1 & 0.84 & 0.648 & 0.751 & 0.87 & 0.62 \\
& CC2 & & 0.751 & 0.840 & & \\
& CC3 & & 0.756 & 0.866 & & \\
\hline
\end{tabular}

Aff. Comt $=$ Affective Commitment, Cont.Comt=Continuance Commitment

\subsection{Convergent Validity}

We used CFA to test convergent validity. In CFA, convergent validity can be assessed by testing each individual item's standardized coefficient greater than the twice its standard error shows that measurement model is significant (Anderson \& Gerbing, 1988). Convergent validity has been empirically assessed by reviewing the t-tests for the factor loadings. In this study all the factor loadings for the indicators measuring the same construct are statistically significant (i.e. greater than twice their standard error), that reflects as evidence supporting the convergent validity of those indicators. In our study all t-tests were significant showing that all indicators are effectively measuring the same construct in the presence of high convergent validity.

\subsection{Discriminant validity}

Discriminant validity measures the extent to which individual items intending to measure one latent construct do not at the same time measure a different latent construct (DeVellis, 1991). In the study Tab.3 can be seen that the average communalities (Average Variance Extracted-AVE) used to measures the each construct are greater than the variance shared with other constructs. Therefore, it is demonstrated that the discriminant validity of all scales is adequate. Moreover, all AVE exceeded 0.50, which indicating strong construct validity. In overall, the measurement results are satisfactory and recommend that it is appropriate to proceed with the investigation and evaluation of the theoretical framework.

\section{ANALYSIS AND RESULTS}

We used SPSS and AMOS-IBM version 21 to analyze the data and demonstrate structural equation modeling (SEM) of this study. It is a powerful multivariate analysis technique used to measure latent variables and investigate causal relationship among proposed model variable. Specifically, SEM allows conducting confirmatory analysis (CFA) for theory development and testing. The overall model fit indices are $\mathrm{x} 2=450.16, \mathrm{df}=231$ ( $\mathrm{p}$-values=0.00), GFI=0.91, AGFI=0.89, $\mathrm{NFI}=0.94$, CFI $=0.97$, RMSEA $=0.049$ indicating that model is acceptable with no substantive differences. Moreover, fit indices of structural model are presented in Table 4 . The factor correlation matrix and standardized parameter estimates of hypothesized paths are presented in Table 5 and 6 respectively. 
Tab. 4 - Fit indices for structural model. Source: Authors Own

\begin{tabular}{|c|c|c|}
\hline Fit Index & Scores & $\begin{array}{l}\text { Recommended cut-off } \\
\text { values }\end{array}$ \\
\hline \multicolumn{3}{|l|}{ Absolute fit Measures } \\
\hline Minimum fit function chi-square (x2) & $450.16(\mathrm{p}=0.00)$ & The lower, the better \\
\hline Degree of freedom (d.f) & 231 & \\
\hline$(\mathrm{x} 2) / \mathrm{d} . \mathrm{f}$ & 1.95 & $<5$ \\
\hline Goodness-of-fit index (GFI) & 0.91 & $>0.80$ \\
\hline Root mean square residual (RMSR) & 0.049 & $<0.05$ \\
\hline \multicolumn{3}{|l|}{ Incremental fit measures } \\
\hline Adjusted goodness-of-fit index (AGFI) & 0.89 & $>0.80$ \\
\hline Tucker-Lewis index (TLI) & 0.96 & $>0.90$ \\
\hline Normal fit index (NFI) & 0.94 & $>0.90$ \\
\hline Comparative fit index (CFI) & 0.97 & $>0.90$ \\
\hline \multicolumn{3}{|l|}{ Parsimonious fit measures } \\
\hline Parsimonious normed fit index (PNFI) & 0.783 & The higher, the better \\
\hline Parsimonious goodness-of-fit index (PGFI) & 0.702 & The higher, the better \\
\hline
\end{tabular}

Tab.5 - Factor Correlation Matrix. Source: Authors Own

\begin{tabular}{|c|c|c|c|c|c|}
\hline Factor & $\begin{array}{l}\text { Information } \\
\text { Quality }\end{array}$ & E-Trust & $\begin{array}{l}\text { Affective } \\
\text { Commitment }\end{array}$ & $\begin{array}{l}\text { E-Satisfac- } \\
\text { tion }\end{array}$ & $\begin{array}{l}\text { Continuance } \\
\text { Commitment }\end{array}$ \\
\hline $\begin{array}{l}\text { Information } \\
\text { Quality }\end{array}$ & 1.000 & & & & \\
\hline E-Trust & 0.125 & 1.000 & & & \\
\hline $\begin{array}{l}\text { Affective } \\
\text { Commitment }\end{array}$ & 0.182 & 0.494 & 1.000 & & \\
\hline E-Satisfaction & 0.557 & 0.276 & 0.358 & 1.000 & \\
\hline $\begin{array}{l}\text { Continuance } \\
\text { Commitment }\end{array}$ & -0.114 & 0.429 & 0.565 & 0.059 & 1.000 \\
\hline
\end{tabular}

Extraction Method: Maximum Likelihood. Rotation Method: Promax with Kaiser Normalization. 


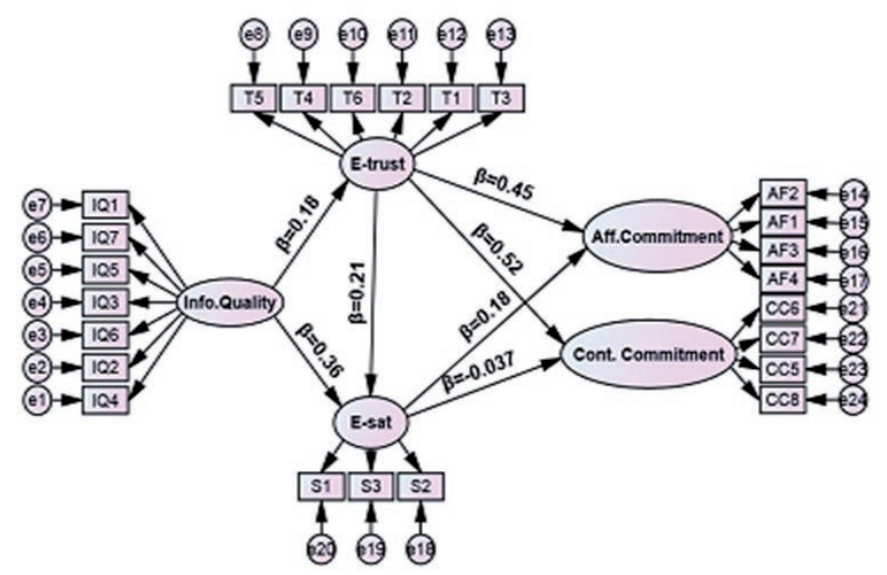

Fig. 2 - Structural equation modeling of the Study. Source: Authors Own

Tab. 6 - Standardized parameter estimates of hypothesized paths. Source: Authors Own

\begin{tabular}{|l|l|l|l|l|l|}
\hline Path & Hypotheses & $\begin{array}{l}\text { Co-efficient } \\
\text { Estimate }\end{array}$ & $\begin{array}{l}\text { Standard } \\
\text { Error }\end{array}$ & t-value & $\mathrm{p}$-value \\
\hline $\begin{array}{l}\text { Information Quality => } \\
\text { E-satisfaction }\end{array}$ & $\mathrm{H} 1$ & 0.361 & .034 & 10.613 & $\mathrm{P}<0.001$ \\
\hline $\begin{array}{l}\text { Information Quality => } \\
\text { E-trust }\end{array}$ & $\mathrm{H} 2$ & 0.180 & .044 & 4.072 & $\mathrm{P}<0.001$ \\
\hline E-trust=> E-satisfaction & $\mathrm{H} 3$ & 0.210 & .041 & 5.111 & $\mathrm{P}<0.001$ \\
\hline $\begin{array}{l}\text { E-satisfaction => Affective } \\
\text { commitment }\end{array}$ & $\mathrm{H} 4$ & 0.180 & .064 & 2.791 & $\mathrm{P}<0.005$ \\
\hline $\begin{array}{l}\text { E-satisfaction }=>\text { Continu- } \\
\text { ance commitment }\end{array}$ & $\mathrm{H} 5$ & -0.037 & .078 & -.481 & $\mathrm{P}=630$ \\
\hline $\begin{array}{l}\text { E-trust }=>\text { Affective com- } \\
\text { mitment }\end{array}$ & $\mathrm{H} 6$ & 0.451 & .057 & 7.893 & $\mathrm{P}<0.001$ \\
\hline $\begin{array}{l}\text { E-trust }=>\text { Continuance } \\
\text { commitment }\end{array}$ & $\mathrm{H} 7$ & 0.527 & .068 & 7.691 & $\mathrm{P}<0.001$ \\
\hline
\end{tabular}

H1: Information quality positively influences e-satisfaction $(\beta=0.36 ; \mathrm{p}<0.001)$. The result supports the finding of (Lin, 2007; Wang and Emurian, 2005; Flavián et al., 2006) who found that information is prerequisite and information quality is the important ingredient of online customers e-satisfaction.

H2: Information quality positively influences e-trust $(\beta=0.18$; $\mathrm{p}<0.001)$. Cyr (2008) investigated that information quality impact on online customers trust in Canada but not in China and Germany. But we examined that information quality influences on e-trust in China. This study confirms the belief that as information quality increases on e-tailers website it will enhanced the 
online customers trust. Our study also support the findings of McKnight et al. (2002) which stated that e-tailers website contents improve customers trust in the context of internet shopping.

H3: E-trust positively influences e-satisfaction $(\beta=0.21 ; \mathrm{p}>.005)$. This study supports the finding of (Harris and Goode, 2004; Jin and Park, 2006; Singh and Sirdeshmukh, 2000) and confirms that e-trust is essential for e-satisfaction.

H4: E-satisfaction positively influences affective commitment $(\beta=0.18 ; \mathrm{p}<0.005)$. This study found that e-tailing satisfaction is significantly associated with affective commitment. As Bansal et al. (2004) explained that online shopping customers' commitment is the consequence of satisfaction. The result of study supports the findings of (Vasudevan et al., 2006; Abdul-Muh$\min , 2005)$.

H5: E-satisfaction positively influences continuance commitment $(\beta=-0.037 ; p>0.005)$. In our study e-satisfaction has not significantly associated with continuance commitment.

H6: E-trust positively influences affective commitment $(\beta=0.45 ; \mathrm{p}<0.001)$. In this study trust play more important role against e-satisfaction in the context of online customers affective commitment. E-trust has stronger relationship with affective commitment but at the same time it is the prerequisite for e-tailing customer's satisfaction. This study supports the findings of De Ruyter et al. (2001).

H7: E-trust positively influences continuance commitment $(\beta=0.52 ; \mathrm{p}<0.001)$. This study supports the findings of De Ruyter et al. (2001). E-trust is the strongest antecedents of continuance commitment in the context of online shopping.

\section{CONCLUSION WITH IMPLICATIONS, LIMITATIONS AND FUTURE RESEARCH DIRECTIONS}

While several authors have focused on multidimensional aspect of e-tailers product quality \& delivery services and the relationship between customer satisfaction, e-trust and customer loyalty. This research sought to establish the bridges between information quality, e-satisfaction, e-trust and commitment of e-tailing. Empirical tests of the model, using a sample of young retail customers, were conducted to support the proposed hypotheses. Specifically, this research contributes to the progress of establishing and measuring the constructs of information quality, e-satisfaction, e-trust and commitment. This study finding provides several managerial implications. The basic premise of the proposed theoretical model was that e-tailers should understand comprehensively the factors that are necessary to improve the e-tailing information quality that will positively impact on e-satisfaction, e-trust and customer's commitment, and use them as diagnostic information. Perhaps, by recognizing and analyzing such diagnostic aspects, e-tailers will be better able to formulate and implement their policies and strategies. The explanation of the research model has the potential to help e-tailers better understand and assess how information quality influences on e-satisfaction, e-trust and commitment. Learning the unexplored relationship between e-tailing information quality, e-satisfaction, e-trust and commitment, e-tailers 
can effectively allocate their resources and develop a rational plan and strategies to improve their e-tail information quality under specific business circumstances.

This study reveals several limitations. Firstly, sampling frame includes universities students that may lead to loss of generalizability of results. Secondly, dependent variable in the hypothesized model, e-satisfaction, e-trust and commitment are likely to be influenced by some other variables instead information quality of e-tailing, which were not the specific object of this study. Therefore, future studies might be conducted to explore the role of e-tailing information quality in the specific brand or product category and it's influenced on customer's commitment.

\section{References}

1. Abdul-Muhmin, A. G. (2005). Instrumental and Interpersonal Determinants of Relationship Satisfaction and Commitment in Industrial Markets. Journal of Business Research, 58(5), 619-628. http://dx.doi.org/10.1016/j.jbusres.2003.08.004

2. Ahluwalia, R. (2000). Examination of Psychological Processes Underlying Resistance to Persuasion. Journal of Consumer Research, 27(2), 217-232. http://dx.doi.org/10.1086/314321

3. Ahn, T., Ryu, S., \& Han, I. (2005). The Impact of the Online and Offline Features on the User Acceptance of Internet Shopping Malls. Electronic Commerce Research and Applications, 3(4), 405-420. http://dx.doi.org/10.1016/j.elerap.2004.05.001

4. Ahn, T., Ryu, S., \& Han, I. (2007). The Impact of Web Quality and Playfulness on User Acceptance of Online Retailing. Information \& Management, 44(3), 263-275. http://dx.doi. org/10.1016/j.im.2006.12.008

5. Allen, N. J., \& Meyer, J. P. (1990). The Measurement and Antecedents of Affective, Continuance and Normative Commitment to the Organization. Journal of Occupational Psychology, 63(1), 1-18. http://dx.doi.org/10.1111/j.2044-8325.1990.tb00506.x

6. Anderson, E. W., Fornell, C., \& Lehmann, D. R. (1994). Customer Satisfaction, Market Share, and Profitability: Findings from Sweden. The Journal of Marketing, 53-66. http:// dx.doi.org/10.2307/1252310

7. Anderson, E., \& Weitz, B. (1992). The Use of Pledges to Build and Sustain Commitment in Distribution Channels. Journal of Marketing Research, 18-34. http://dx.doi. org $/ 10.2307 / 3172490$

8. Anderson, J. C., \& Gerbing, D. W. (1988). Structural Equation Modeling in Practice: A Review and Recommended Two-Step Approach. Psychological Bulletin, 103(3), 411-423. http:// dx.doi.org/10.1037//0033-2909.103.3.411

9. Bai, B., Law, R., \& Wen, I. (2008). The Impact of Website Quality on Customer Satisfaction and Purchase Intentions: Evidence from Chinese Online Visitors. International Journal of Hospitality Management, 27(3), 391-402. http://dx.doi.org/10.1016/j.ijhm.2007.10.008

10. Bansal, H. S., Irving, P. G., \& Taylor, S. F. (2004). A Three-Component Model of Customer to Service Providers. Journal of the Academy of Marketing Science, 32(3), 234-250. http://dx.doi. org/10.1177/0092070304263332

11. Berry, L. L. (2000). Cultivating Service Brand Equity. Journal of the Academy of Marketing Science, 28(1), 128-137. http://dx.doi.org/10.1177/0092070300281012 
12. Bharati, P., \& Chaudhury, A. (2004). An Empirical Investigation of Decision-Making Satisfaction in Web-Based Decision Support Systems. Decision Support Systems, 37(2), 187-197. http://dx.doi.org/10.1016/s0167-9236(03)00006-x

13. Brown, T. J., Barry, T. E., Dacin, P. A., \& Gunst, R. F. (2005). Spreading the Word: Investigating Antecedents of Consumers' Positive Word-of-Mouth Intentions and Behaviors in a Retailing Context. Journal of the Academy of Marketing Science, 33(2), 123-138. http://dx.doi.org/10.1177/0092070304268417

14. Chuan-Chuan Lin, J., \& Lu, H. (2000). Towards an Understanding of the Behavioural Intention to Use a Web Site. International Journal of Information Management, 20(3), 197-208. http://dx.doi.org/10.1016/s0268-4012(00)00005-0

15. Cyr, D. (2008). Modeling Web Site Design Across Cultures: Relationships to Trust, Satisfaction, and E-Loyalty. Journal of Management Information Systems, 24(4), 47-72. http:// dx.doi.org/10.2753/mis0742-1222240402

16. De Ruyter, K., Moorman, L., \& Lemmink, J. (2001). Antecedents of Commitment and Trust in Customer-Supplier Relationships in High Technology Markets. Industrial Marketing Management, 30(3), 271-286. http://dx.doi.org/10.1016/s0019-8501(99)00091-7

17. DeVellis, R.F. (1991). Scale Development: Theory and Applications. Newbury Park, CA: Sage Publications.

18. Dwyer, F. R., Schurr, P. H., \& Oh, S. (1987). Developing Buyer-Seller Relationships. The Journal of Marketing, 51(2), 11-27. http://dx.doi.org/10.2307/1251126

19. Flavián, C., Guinalíu, M., \& Gurrea, R. (2006). The Role Played by Perceived Usability, Satisfaction and Consumer Trust on Website Loyalty. Information \& Management, 43(1), 1-14. http://dx.doi.org/10.1016/j.im.2005.01.002

20. Fornell C, Johnson MD, Anderson EW, Cha J, Bryant BE (1996) The American Customer Satisfaction Index: Nature, Purpose, and Findings. Journal of Marketing, 60(4). http://dx.doi. org $/ 10.2307 / 1251898$

21. Fullerton, G. (2003). When Does Commitment Lead to Loyalty? Journal of Service Research, 5(4), 333-344. http://dx.doi.org/10.1177/1094670503005004005

22. Fung Business Intelligence Center (2013). Online retailing in China 2013. Retrieved from http://www.funggroup.com/eng/knowledge/research/china_dis_issue111.pdf

23. Garbarino, E., \& Johnson, M. S. (1999). The Different Roles of Satisfaction, Trust, and Commitment in Customer Relationships. The Journal of Marketing, 63(2), 70-87. http://dx.doi. org $/ 10.2307 / 1251946$

24. Gundlach, G. T., Achrol, R. S., \& Mentzer, J. T. (1995). The Structure of Commitment in Exchange. The Journal of Marketing, 59(1), 78-92. http://dx.doi.org/10.2307/1252016

25. Hair, J. F., Black, W. C., Babin, B. J., Anderson, R.E. \& Tatham, R. L. (2006). Multivariate Data Analysis. NJ: Pearson Prentice Hall.

26. Hair, J. F., Tatham, R. L., Anderson, R. E. \& Black, W. (1998). Multivariate data analysis. (Fifth Ed.). London: Prentice-Hall. 
27. Harris, L. C., \& Goode, M. M. (2004). The Four Levels of Loyalty and the Pivotal Role of Trust: a Study of Online Service Dynamics. Journal of Retailing, 80(2), 139-158. http://dx.doi. org/10.1016/j.jretai.2004.04.002

28. Janda, S., Trocchia, P. J., \& Gwinner, K. P. (2002). Consumer Perceptions of Internet Retail Service Quality. International Journal of Service Industry Management, 13(5), 412-431. http:// dx.doi.org/10.1108/09564230210447913

29. Jin, B., \& Park, J. Y. (2006). The Moderating Effect of Online Purchase Experience on the Evaluation of Online Store Attributes and the Subsequent Impact on Market Response Outcomes. Advances in Consumer Research, 33, 203.

30. Kasmer, H. (2005), Customer Relationship Management, Customer Satisfaction Study and a Model for Improving Implementation of the Maritime Transport Sector, Systems Engineering Program of the U.S. prepared YTU FBE Master's thesis in Industrial Engineering, Istanbul.

31. Kim, J., Jin, B., \& Swinney, J. L. (2009). The Role of Etail Quality, E-Satisfaction and ETrust in Online Loyalty Development Process. Journal of Retailing and Consumer Services, 16(4), 239-247. http://dx.doi.org/10.1016/j.jretconser.2008.11.019

32. Kim, W. G., Leong, J. K., \& Lee, Y. K. (2005). Effect of Service Orientation on Job Satisfaction, Organizational Commitment, and Intention of Leaving in a Casual Dining Chain Restaurant. International Journal of Hospitality Management, 24(2), 171-193. http://dx.doi. org/10.1016/j.ijhm.2004.05.004

33. Lederer, A. L., Maupin, D. J., Sena, M. P., \& Zhuang, Y. (2000). The Technology Acceptance Model and the World Wide Web. Decision Support Systems, 29(3), 269-282. http:// dx.doi.org/10.1016/s0167-9236(00)00076-2

34. Lightner NJ, Yenisey MM, Ozok AA, Salvendy G (2002) Shopping Behaviour and Preferences in E-Commerce of Turkish and American University Students: Implications from Cross-Cultural Design. Behaviour \& Information Technology, 21(6), 373-385. http://dx.doi. org/10.1080/0144929021000071316

35. Lin, H. F. (2007). The Impact of Website Quality Dimensions on Customer Satisfaction in the B2C E-Commerce Context. Total Quality Management and Business Excellence, 18(4), 363378. http://dx.doi.org/10.1080/14783360701231302

36. Liu, C., Arnett, K. P., \& Litecky, C. (2000). Design Quality of Websites for Electronic Commerce: Fortune 1000 Webmasters' Evaluations. Electronic Markets, 10(2), 120-129. http://dx.doi.org/10.1080/10196780050138173

37. McKnight, D. H., Choudhury, V., \& Kacmar, C. (2002). Developing and Validating Trust Measures for E-Commerce: An Integrative Typology. Information Systems Research, 13(3), 334359. http://dx.doi.org/10.1287/isre.13.3.334.81

38. Moorman, C., Zaltman, G., \& Deshpande, R. (1992). Relationships between Providers and Users of Market Research: The Dynamics of Trust. Journal of Marketing Research, 29(3), 314328. http://dx.doi.org/10.2307/3172742

39. Morgan, R. M., \& Hunt, S. D. (1994). The Commitment-Trust Theory of Relationship Marketing. The Journal of Marketing, 58(3), 20-38. http://dx.doi.org/10.2307/1252308 
40. Nunnally J.C. (1978). Psychometric Theory (2) New York: McGraw-Hill.

41. Palmer, J. W. (2002). Web Site Usability, Design, and Performance Metrics. Information Systems Research, 13(2), 151-167. http://dx.doi.org/10.1287/isre.13.2.151.88

42. Park, C. H., \& Kim, Y. G. (2003). Identifying Key Factors Affecting Consumer Purchase Behavior in an Online Shopping Context. International Journal of Retail \& Distribution Management, 31(1), 16-29. http://dx.doi.org/10.1108/09590550310457818

43. Poddar, A., Donthu, N., \& Wei, Y. (2009). Web Site Customer Orientations, Web Site Quality, and Purchase Intentions: The Role of Web Site Personality. Journal of Business Research, 62(4), 441-450. http://dx.doi.org/10.1016/j.jbusres.2008.01.036

44. Pritchard, M. P., Havitz, M. E., \& Howard, D. R. (1999). Analyzing the CommitmentLoyalty Link in Service Contexts. Journal of the Academy of Marketing Science, 27(3), 333-348. http://dx.doi.org/10.1177/0092070399273004

45. Ranganathan, C., \& Ganapathy, S. (2002). Key Dimensions of Business-to-Consumer Web Sites. Information \& Management, 39(6), 457-465. http://dx.doi.org/10.1016/s03787206(01)00112-4

46. Ribbink, D., Van Riel, A. C., Liljander, V., \& Streukens, S. (2004). Comfort Your Online Customer: Quality, Trust and Loyalty on the Internet. Managing Service Quality, 14(6), 446456. http://dx.doi.org/10.1108/09604520410569784

47. Singh, J., \& Sirdeshmukh, D. (2000). Agency and Trust Mechanisms in Consumer Satisfaction and Loyalty Judgments. Journal of the Academy of Marketing Science, 28(1), 150-167. http://dx.doi.org/10.1177/0092070300281014

48. Sirdeshmukh, D., Singh, J., \& Sabol, B. (2002). Consumer Trust, Value, and Loyalty in Relational Exchanges. Journal of Marketing, 66(1), 15-37. http://dx.doi.org/10.1509/ jmkg.66.1.15.18449

49. Tellefsen, T. (2002). Commitment in Business-to-Business Relationships: The Role of Organizational and Personal Needs. Industrial Marketing Management, 31(8), 645-652. http:// dx.doi.org/10.1016/s0019-8501(01)00172-9

50. Vasudevan, H., Gaur, S. S., \& Shinde, R. K. (2006). Relational Switching Costs, Satisfaction and Commitment: A Study in the Indian Manufacturing Context. Asia Pacific Journal of Marketing and Logistics, 18(4), 342-353. http://dx.doi.org/10.1108/13555850610703281

51. Verhoef, P. C., Franses, P. H., \& Hoekstra, J. C. (2002). The Effect of Relational Constructs on Customer Referrals and Number of Services Purchased from a Multiservice Provider: Does Age of Relationship Matter? Journal of the Academy of Marketing Science, 30(3), 202-216. http://dx.doi.org/10.1177/0092070302303002

52. Vijayasarathy, L. R. (2004). Predicting Consumer Intentions to Use On-line Shopping: the Case for an Augmented Technology Acceptance Model. Information \& Management, 41(6), 747-762. http://dx.doi.org/10.1016/j.im.2003.08.011

53. Wang, Y. D., \& Emurian, H. H. (2005). Trust in E-Commerce: Consideration of Interface Design Factors. Journal of Electronic Commerce in Organizations, 3(4), 42-60. http://dx.doi. org/10.4018/jeco.2005100103 
54. Yoon, S. J. (2002). The Antecedents and Consequences of Trust in Online Purchase Decisions. Journal of Interactive Marketing, 16(2), 47-63. http://dx.doi.org/10.1002/dir.10008

\section{Contact information}

Muhammad Ziaullah (Ph.D Sholar),

Dr. Feng Yi (Associate Professor),

Shumaila Naz, Akbter (MS in Management Candidate)

School of Management and Economics

University of Electronic Science and Technology of China

Qingshuibe Campus: No. 2006, Xiyuan Ave, West Hi-Tech Zone, 611731

Chengdu, Sichuan, P.R.China

ziacadgk@gmail.com

Muhammad Fahad Khan

Capital Development Authority, G-7/3-4, Islamabad, Pakistan 